\title{
Palynomorphs of brackish and marine species in cores from the freshwater Lake Sapanca, NW
}

\section{Turkey}

\author{
Suzanne A. G. Leroy*1 and Meriç Albay ${ }^{2}$
}

* Corresponding author: tel: +44-1895-266087; fax: +44-1895-269761;

suzanne.leroy@brunel.ac.uk

1 Institute for the Environment, Brunel University, Uxbridge UB8 3PH (West

London), UK

2 Department of Inland Waters, Faculty of Fisheries, University of Istanbul, Ordu Cad. No: 20034470 Laleli, Istanbul, Turkey

\section{Abstract}

Lake Sapanca, which is located on the Sakarya-Sapanca-İzmit corridor in NW Turkey, is a freshwater lake with numerous fish farms in its catchment. Palynological analyses including non-pollen palynomorphs of a short $(38.5 \mathrm{~cm})$ and a longer sediment core $(586 \mathrm{~cm})$, taken in the centre of the lake and dated in previous investigations, revealed the presence of brackish and marine palynomorphs. The longer sediment sequence shows the occurrence of Brigantedinium sp., Impagidinium caspienense and Spiniferites cruciformis from 
the base of the core at c. AD 580 years up to $300 \mathrm{~cm}$ depth at shortly after c. AD 910. A similar assemblage, but this time with the additional presence of dinoflagellate thecae and the acritarch, Radiosperma corbiferum, was found in the recent core, especially from AD 1986 until the present. Past connections between the Gulf of İmit and the Black Sea, via the River Sakarya and Lake Sapanca, could be the origin of these two microfossil assemblages. Accidental re-introduction via fish translocation since the Roman times may have been a supplement mechanism. The consequences of the survival of brackish and marine forms in a freshwater lake are discussed in terms of wider euryhalinity than has been suggested for those still poorly known organisms.

\section{Key words}

Lake Sapanca; palaeogeography; palynomorphs; lake sediment; Black Sea; Sakarya Strait; fish translocation; dinocysts 


\section{Introduction}

The freshwater lake, Lake Sapanca in NW Turkey, is a key area of interest to earth scientists. The lake is located on an active strand of the North Anatolian Fault Zone (NAFZ). It is located at a possible palaeo-connection (the Sakarya Strait) between the Black Sea and the Marmara Sea, bypassing and predating the Strait of İstanbul (Ryan and Pitman, 1998; Gürbüz and Leroy, 2010) (Fig. 1).

At the time of pollen analyses on a short Kajak core $(38.5 \mathrm{~cm})$ and a longer Reasoner core $(586 \mathrm{~cm})$ taken from Lake Sapanca, the occasional presence of microfossils typical of brackish and marine waters has been detected (Leroy et al., 2009; Leroy et al., in press), but no discussion as to the causes of their presence has been provided so far. Here we compare the fossil record of these two cores and suggest explanations for their origin.

Fig. 1

\section{Setting and previous studies}

\subsection{The lake}

Lake Sapanca is located at $40^{\circ} 43^{\prime} \mathrm{N}, 30^{\circ} 15^{\prime} \mathrm{E}$ and an altitude of $31 \mathrm{~m}$ asl (Figs 1 and 2). The lake occupies a pull-apart basin, created by a step-over in fault rupture (Rathje et al., 2004).

Fig, 2

This freshwater lake has a surface area of $46.8 \mathrm{~km}^{2}$, a maximum depth of 
$55 \mathrm{~m}$, which is below sea level, and stretches $16 \mathrm{~km}$ in an East-West direction and 5 km in a South-North direction (Albay et al., 2003; Fig. 2). The whole water column of Lake Sapanca mixes once a year in February-March and surface waters cool down to $6.5^{\circ} \mathrm{C}$ by late winter and then warm steadily to $26{ }^{\circ} \mathrm{C}$ by late summer. Thus Lake Sapanca is a warm monomictic freshwater lake (Morkoç et al., 1998). According to Baykal et al. (1996), the lake is oligotrophic with a first class quality, but tends to become slightly mesotrophic. Recent measurements (2008-2009) of salinity through the water column indicate values always lower than $1 \%$.

The unexpected development of tourism and recreation at the beginning of the 1990s has given rise to excessive nutrient input to the lake (Table 1). At present, the lake provides drinking water for the district of Sakarya and Kocaeli. It is also used for agriculture and abstracted for industrial use (Albay and Akçaalan, 2008). The physical, chemical and biological characters of Lake Sapanca are summarized in Table 1.

Fifteen rivers, many of them ephemeral, feed the lake with the largest inflows from the south. Lake Sapanca discharges via River Çark on the northeast shore into Sakarya River (Figs 1 and 2). This larger river is $5 \mathrm{~km}$ east of the lake, but can occasionally overflow into it.

As three other papers deriving from the same research project as this paper have already been published, much of the setting descriptions, such as climate, vegetation, geology, and relief, can be found in Schwab et al. (2009) and Leroy et al. (2009, in press).

\subsection{Palaeogeography of the region and historical palaeo-connections}

The Black Sea formed as the Paratethys progressively shrunk and split in 
several seas (Vasiliev et al., 2004). Pfannenstiel (1944) referring to Andrussow's work suggested that the Black Sea was connected with the Marmara Sea via the Lower Sakarya Valley-Lake Sapanca-İzmit Gulf waterway during different intervals of the Pleistocene and that the valley between the Black Sea and the Gulf of İmit (Figs. 1 and 2) was an arm of the sea during what he referred to as 'the diluvial times', corresponding to the last melting of the Eurasian ice sheet (Ryan and Pitman, 1998). This passage was progressively severed by tectonic movements during the transition from the Late Pleistocene to the Holocene and replaced by the İstanbul Strait at an unknown time. The role of the Sakarya Strait cannot be understated, as it would have served as a sill for the connection between the Black Sea and the Mediterranean Sea. Therefore it would have played a major part in controlling the height of the Black Sea, then a lake (Ryan, 2007).

Water connections between the Marmara Sea and Lake Sapanca in the past 2000 years have featured in some historical documents (Gürbüz and Leroy, 2010). 1) Titus Livius (59 years BC to AD 17) described the Sakarya River as flowing to the Marmara Sea at the beginning of the first millennium AD. 2) Caius Plinius Secundus (AD 23-79) suggested constructing a canal from Lake Sapanca to a small river flowing into the İzmit Gulf for good transport purposes. 3) At the time of Emperor Hadrianus (AD 76-138), the great earthquake of $A D$ 123 flooded the marshy plain between Lake Sapanca and the İmit Gulf, which could be drained by opening a canal to the sea. 4) Evliya Çelebi (AD 16111692) mentioned a temporary artificial waterway between the Marmara Sea and Lake Sapanca made a short time after AD 286. It is likely that these brief revivals of parts of a longer waterway reflect an earlier continuous connection 
(Gürbüz and Leroy, 2010).

\subsection{Fauna in Lake Sapanca and neighbouring lakes}

In Turkey most of the fisheries are state owned. On the shores of Lake Sapanca, the first fishery started in 1979, as part of the University of Istanbul with a large research station where many species of fishes were kept. Private fisheries were allowed only until the late 1990s when they became banned by the government in order to preserve the water quality of the lake. In addition more than 30 independent small trout farms have developed in the catchment area of Lake Sapanca (Albay et al., 2003).

Since the investigations of Ongan (1982), a noticeable change in the fish fauna of Lake Sapanca has been observed with a decrease of the economical species (Esox linus, Cyprinus carpio, Scardinius erythrophthalmus and Silurus glanis) in favour of non-economical ones (several Cyprinidae species) (Karabatak and Okgerman, 2002). According to recent studies in the lake, some catadromous species like Anguilla anguilla, anadromous species like Salmo salar and some marine-based fish, like Syngnathus abaster, have seen a drastic reduction of their population because of disruption and pollution by residential and agricultural usage (Tarkan and Gaygusuz, unpublished data). Moreover two new invasive species have been observed since 2000 (Carassius gibelio and Lepomis gibbosus) (Şaşı and Balık, 2003). Salmo salar (Atlantic salmon) in Lake Sapanca research station comes from the Black Sea (Innal and Erkakan, 2006). Acipenser gueldenstaedtii (Russian sturgeon) is experimentally grown in Lake Sapanca from eggs from Krasnodar (a Russian town where the Black and Azov Seas meet) (Çelikkale et al., 2005). 
Several marine or brackish life forms survive in Lake Sapanca: a Ctenophore jellyfish, Craspedacusta sp., the black-striped pipefish Syngnathus abaster and some species of molluscs, Theodoxus sp. and Esperiana esperi (Pfannenstiel, 1944; Şahin and Yıldırım, 2007). The brackish mussel, Dreissena polymorpha, is believed to have been present in Anatolian lakes for several millions of years as a survival of the Tethys Sea (Bobat et al., 2004). Nowadays it is present in large quantities in Lake Sapanca following a recent increase over the last two decades. Schütt (1988) analysed the freshwater mollusc fauna of Lake Sapanca and showed that several species belong to the Danubian fauna.

The survival of brackish marine species is however not unique to Lake Sapanca: for example Craspedacusta, Syngnathus abaster and Theodoxus anatolicus are also found in other lakes (Boettger, 1957; Balık et al., 2001; Uğurlu and Polat, 2006; Özuluğ, 2008; Polat et al., 2008).

İslamoğlu (2008) discovered two brackish bivalves in Middle Pleistocene terraces along Lake İznik (70 km south-west of Lake Sapanca) demonstrating closed affinities with the Ponto-Caspian regions.

\section{Material and methods}

The two cores were taken from the centre of the lake. Their sediment consists of clayey silt with rare sand layers. The Kayak core (SA03K7.1 or K7), $38.5 \mathrm{~cm}$ long, was dated by the radionuclide method $\left({ }^{137} \mathrm{Cs}\right.$ and $\left.{ }^{210} \mathrm{~Pb}\right)$ providing an age of c. AD 1950 at the base of the sequence (Schwab et al., 2009). The chronology of the Reasoner core (SA03R6 or R6), $596 \mathrm{~cm}$ long, was obtained by a series of radiocarbon dates (Leroy et al., in press). The lower part of the core consists of a landslide. A date of c. AD 580 (top of the landslide) at $448 \mathrm{~cm}$ depth indicates that the sequence formed over the last 1500 years. Both records 
are frequently interrupted by earthquake-related events (Schwab et al., 2009; Leroy et al., 2009; in press). Because of loss of sediment during coring with the Reasoner technique, it is likely that the two sequences (Kayak core and Reasoner core) hardly overlap.

Core $\mathrm{K} 7$ has been sampled at a very high resolution. Below $10.25 \mathrm{~cm}$ depth, 0.25-cm-thick samples were then taken and analysed at 1-cm spacing. Contiguous 0.25 -cm-thick samples were taken between $10.25 \mathrm{~cm}$ and the core top. Core R6 has been sampled at a lower resolution: every $7 \mathrm{~cm}$ below $448 \mathrm{~cm}$ and every $25 \mathrm{~cm}$ above that depth.

The samples were processed using the following protocol $-\mathrm{Na}_{4} \mathrm{P}_{2} \mathrm{O}_{7}, \mathrm{HCl}$, $\mathrm{HF}, \mathrm{HCl}$ treatments, and 125 and $10 \mu \mathrm{m}$ sieving, with no acetolysis. Slides were made by mounting some of the residue in a glycerol medium. Palynomorphs were routinely counted under a light microscope at a magnification of $400 x$ and at $1000 x$ for special identification. Dinoflagellate cysts were identified using the taxonomy for the Caspian Sea of Marret et al. (2004). Microphotographs were taken at 1000x with an Olympus digital camera C3030, 3.3 megapixels. Microfossil diagrams were plotted using the software psimpoll4.10 (Bennett, 2007). The percentages of microfossil presented here were calculated on the sum of terrestrial pollen (Leroy et al., 2009; in press). Concentrations (number of microfossils per ml of wet sediment) were calculated based on the addition of Lycopodium tablets at the beginning of the palynomorph extraction.

\section{Results}

Fig. 3 


\subsection{Species list and geographical distribution}

The phytoplankton of Lake Sapanca has been studied in detail in the last two decades (Aykulu et al., 2006; Akçaalan et al., 2007). The dinoflagellate thecae are in low numbers $(<2 \%)$ and are represented by Ceratium hirundinella and Peridinium bipes. It is necessary to state that the theca forms of the dinocyst species found in Lake Sapanca are not known (Leroy et al., 2006).

The dinoflagellate cysts Spiniferites cruciformis, Brigantedinium sp. and Impagidinium caspienense were found in the cores (Fig. 3). Spiniferites cruciformis was first described from Late Quaternary sediments of the Black Sea (Wall et al., 1973). Subsequently it has been found in Late Quaternary sequences from the Marmara Sea and the NE Aegean Sea (Aksu et al., 1995; Mudie et al., 2001), in Early Pliocene sediments from the Ptolemais Basin in northern Greece (Kloosterboer-van Hoeve et al., 2000), in Late Glacial sediments from the freshwater Lake Kastoria in northern Greece (Kouli et al., 2001) and since the Lateglacial in the Caspian Sea (Marret et al., 2004; Leroy, $2000 ; 2006 ; 2007)$. The preservation of cytoplasm in some of the S. cruciformis specimens in the top $\mathrm{cm}$ of core $\mathrm{K} 7$ indicates the recent sedimentation of living organisms and therefore the absence of reworking of old sediment. Most of the S. cruciformis are specimens with rather short processes, such as in the photo of figure 3, or even shorter. The heterotrophic taxon, Brigantedinium sp. is abundant in many environments. Their presence is related to nutrient-rich conditions (e.g. Marret and Zonneveld, 2003). "Baggy cysts" have been documented from Neogene sediments of the Black Sea (Traverse, 1978). They are also frequent in the Holocene sediment of the Caspian, Black and Marmara Seas (Mudie et al., 2002; Leroy et al., 2006; Leroy et al., 2007; Marret et al., 
2009). I. caspienense is a new species recently described in the Caspian Sea (Marret et al., 2004; Leroy et al., 2006). Its high number in the Caspian Sea sediments suggest that this species is more tolerant to lower salinity than other Impagidinium species (Marret et al., 2004). It has recently been identified in the Black Sea sediments but in very low numbers (Marret et al., 2009).

Radiosperma corbiferum (Fig. 3), which is present in the Celtic, Benguela, Baltic and Aral Seas, is generally considered a brackish and marine organism (Sorrel et al., 2006; Mertens et al., 2009). Its biological affinity remains however unknown. It is rare in the Black Sea (P. Mudie, personal communication, 2008; Mudie et al., in press) and present in the Caspian Sea (Leroy et al., 2007 and unpublished data).

\subsection{Distribution in the two cores}

In core $\mathrm{K} 7$, the thecae of dinoflagellates were present only above $6 \mathrm{~cm}$ depth; their distribution in the core was probably limited by preservation (Fig. 4). Brigantedinium sp. is observed mostly above $10 \mathrm{~cm}$ depth with one exception at $18 \mathrm{~cm}$. Single occurrences of $l$. caspienense have been found in four samples between 14 and $8 \mathrm{~cm}$ depth. S. cruciformis clearly occurs only, but continuously, above $11 \mathrm{~cm}$ depth, hence above the ${ }^{137} \mathrm{Cs}$ peak linked to Chernobyl accident of AD 1986. R. corbiferum is present throughout the sequence forming a subcontinuous curve, hence since c. AD 1950.

Fig. 4

In core R6, S. cruciformis, Brigantedinium sp. and I. caspienense were recovered below $300 \mathrm{~cm}$ depth (Fig. 4). The latter two dinocysts showed only 
single occurrences whereas the first one displayed a subcontinuous curve. It is worth noting the absence of $R$. corbiferum. The bottom of the core is dated at $\mathrm{c}$. AD 580 and the depth of $300 \mathrm{~cm}$ is dated shortly after c. AD 910 (Leroy et al., in press).

\section{Origin of the brackish and marine microfossils}

Four mechanisms may explain the presence of these brackish and marine microfossils in Lake Sapanca.

Firstly, palaeoconnections of the lake with the Black Sea have taken place in the past. An old connection with the Paratethys has been suggested to explain the presence of Paratethysian and Danubian species in lakes of NW Anatolia. Therefore such an origin for the microfossils of Sapanca has to be considered. Then during the Late Pleistocene and/or the earliest Holocene a more restricted connection via the Sakarya-Sapanca-İmit corridor is possible, although debated by the scientific community. In addition most of the historical documents describing contacts with the Sea of Marmara (Gürbüz and Leroy, 2010) discuss periods around 2000 years ago, therefore periods slightly older than the ages of the microfossils recorded in core R6. The Black Sea dinocysts, abundant in the early Holocene and rare but present in the late Holocene (Mudie et al., 2004), may have survived in Lake Sapanca. The dinoflagellates have a well-known capacity of survival during periods of unfavourable conditions (e. g. low nutrients) by encystment in the sediment for periods that may reach several decades (Anderson et al., 1987). This characteristic may have helped them to maintain a population through the changing environmental conditions that the lake has undergone since the last full connection with the Black Sea. 
Secondly, it is well known that the Romans commonly operated fish translocation, for example with wild carps (Cyprinus carpio) from the River Danube to Italy and Greece (Balon, 1995) and that aquaculture allows transferring water with their micro-organisms to other water bodies alongside fishes. Although it is not established if this precisely occurred in Lake Sapanca, the town of Sapanca was quite developed in Roman Bithynia because situated on a major road between the Bosphorus and the eastern provinces. Fish translocations remain common practice in modern Turkey (Innal and Erkakan, 2006).

Thirdly, waterbird transport of pollen, phytoplankton and other small organisms over hundreds of $\mathrm{km}$ is a mechanism frequently cited for the colonisation of isolated water bodies (Atkinson, 1980; Kristiansen, 1996; Santamaría and Klaassen, 2002; McAndrews and Turton, 2006). It takes place with sediment stuck on their bodies (plumage, bill or legs) or in their digestive track (Atkinson, 1980). The mechanism of avian dispersion may have played a significant role in the case of Lake Sapanca, especially with the Black and the Marmara Seas at short flight distance.

Fourthly, catadromous and anadromous fishes would transport microorganisms to the lake by their seasonal contacts with the sea. This mechanism would have started at the time when Lake Sapanca became freshwater.

Knowing that the microfossils found in the palynological record are not the only organisms from brackish and marine environment found in Lake Sapanca and that other lakes have also brackish and marine forms living in them, the best hypotheses are therefore the following: survival from the Paratethys supplemented by fish introduction. 
In either case, 1) a range of micro-organisms must have been introduced by one of these mechanisms but only few species survived; and 2) those that survived appear to have been able to tolerate freshwater.

\section{Conclusions}

The unexpected presence of brackish and marine microfossils has been observed in the sedimentary records of Lake Sapanca, a freshwater body in NW Turkey. Two periods especially favourable for their development were recorded: the last 30 years and the period from at least 1500 years ago to c. 1100 years ago.

The marine and brackish microfossils are suggested be the remaining signs of an ancient palaeo-connection between the Black and the Marmara Seas. Fish translocation over the last 2000 years may have in addition brought a range of micro-organisms directly from the Black and the Caspian Seas.

Finding these brackish and marine microfossils in Lake Sapanca, a freshwater lake, indicate their wide tolerance to very low salinities, for some (for example $R$. corbiferum), wider than so far acknowledged.

\section{Acknowledgements}

This study was funded by the European Union as part of the EC Project RELIEF (EVG1-CT-2002-00069). This is a contribution to IGCP 521 "Black SeaMediterranean Corridor during the last 30 ky: sea level change and human adaptation", working group 2 on Palynology. The authors are grateful to F. Marret (Liverpool University) for the confirmation of the identifications. 


\section{References}

Akçaalan, R., Albay, M., Gürevin, C., Çevik, F., 2007. The influence of environmental conditions on the morphological variability of phytoplankton in an oligo-mesotrophic Turkish lake. Annales de Limnologie 43, 1, 21-28.

Aksu, A.E., Yasar, D., Mudie, P.J., Gillespie, H., 1995. Late glacial-Holocene paleoclimatic and paleoceanographic evolution of the Aegean Sea: micropaleontological and stable isotopic evidence. Marine Micropaleontology 25, 1-28.

Albay, M., Akçaalan, R., 2008. Effects of water quality and hydrologic drivers on periphyton colonization on Sparganium erectum in two Turkish lakes with different mixing regimes. Environmental Monitoring and Assessment 146, $171-181$

Albay, M., Akcaalan, R., Tufekci, H., Metcalf, J.S., Beattie, K.A., Codd, G.A., 2003. Depth profiles of cyanobacterial hepatotoxins (microcystins) in three Turkish freshwater lakes. Hydrobiologia 505, 1-3, 89-95.

Anderson, D.M., Taylor, C.D., Armbrust, E.V., 1987. The effects of darkness and anaerobiosis on dinoflagellate cyst germination. Limnology and Oceanography 32, 2, 340-351.

Atkinson, K.M., 1972. Birds as transporters of algae. European Journal of Phycology, 7: 3, $319-321$.

Aykulu, G., Albay, M., Tüfekçi, H., Aktan, Y., 2006. Species composition, abundance and seasonality of phytoplankton in a moderately deep Turkish lake. Nowa Hedwigia 130, 325-338. 
Balık, S., Ustaoğlu, M. R., Özbek, M., 2001. A new locality for the freshwater jellfish Craspedacusta sowerbyi Lankester, 1880 in Turkey. Zoology in the Middle East, Kasparek Verlag, Heidelberg, 22, 133-134

Balon, E.K., 1995. Origin and domestication of the wild carp, Cyprinus carpio: from Roman gourmets to the swimming flowers. Aquaculture 129, 3-48.

Baykal, B.B., Gonenc, I.E., Meric, M., Tanik, A., Tunay, O., 1996. An alternative approach for evaluation of lake water quality: Lake Sapanca - A case study from Turkey. Water Science and Technology 34, 73-81.

Bennett, K., 2007. psimpoll and pscomb programs for plotting and analysis.

Version psimpoll 4.10. http://www.chrono.qub.ac.uk/psimpoll/psimpoll.html. (accessed April 2009).

Bobat, A., Hengirmen, M. O., Zapletal, W., 2004. Zebra Mussel and Fouling

Problems in the Euphrates Basin. Turkish Journal of Zoology 28, 161-177.

Boettger, C., 1957. Über eine Ausbeute von Höhlenmollusken und einigen anderen Weichtieren aus der Türkei. Archiv für Molluskenkunde 86, 1/3, 67-83.

Çelikkale, M.S., Memiş, D., Ercan, E., Çağıltay, F., 2005. Growth performance of juvenile Russian sturgeon (Acipenser gueldenstaedtii Brandt \& Ratzenburg, 1833) at two stocking densities in net cages. Journal of Applied Ichthyology 21, 1, 14-18.

Gürbüz, A., Leroy, S.A.G., 2010. Science versus Myth: Was there a connection between the Marmara Sea and Lake Sapanca? March 2009 Journal of Quaternary Science 25, 2, 103-114.

Innal, D., Erkakan, F., 2006. Effects of exotic and translocated fish species in the inland waters of Turkey. Reviews in Fish Biology and Fisheries 16, 39- 
50.

İslamoğlu, Y., 2008. Middle Pleistocene bivalves of the İznik lake basin (Eastern Marmara, NW Turkey) and a new paleobiogeographical approach. International Journal of Earth Sciences DOI 10.1007/s00531-008-0344-x. Karabatak, M., Okgerman, H., 2002. Sapanca Gölü Ekonomik Balık Türlerinin Kompozisyonu, Popülasyon Bolluğu ve Boy Dağılımları Üzerine Bir Ön Çalışma. İstanbul Üniversitesi, Su Ürünleri Dergisi 13, 81-98.

Kloosterboer-van Hoeve, M.L., 2000. Cyclic changes in the late Neogene vegetation of northern Greece, a palynological study. Ph.D. thesis, LPP Contributions series nำ12, LPP Foundation-Utrecht.

Kouli, K., Brinkhuis, H., Dale, B., 2001. Spiniferites cruciformis: a freshwater dinoflagellate cyst? Review of Paleobotany and Palynology 133, 273-286.

Kristiansen, J., 1996. Dispersal of freshwater algae - a review. Hydrobiologia $336,151-157$.

Leroy, S.A.G., Boyraz, S., Gürbüz, A., 2009. High-resolution palynological analysis in Lake Sapanca as a tool to detect earthquakes on the North Anatolian Fault. Quaternary Science Reviews 28: 2616-2632.

Leroy, S., Marret, F., Gasse, F., Chalié, F., 2000. Understanding the Caspian Sea erratic fluctuations: palynological results from the south basin. ELDPESF meeting, Pallanza, Italy. 7-12 Oct. 2000. Extended abstract,Terra Nostra 7, 45-49.

Leroy, S.A.G., Marret, F., Gibert, E., Chalié, F., Reyss, J-L., Arpe, K., 2007. River inflow and salinity changes in the Caspian Sea during the last 5500 years. Quaternary Science Reviews 26, 3359-3383. 
Leroy, S.A.G., Marret, F., Giralt, S., Bulatov, S.A., 2006. Natural and anthropogenic rapid changes in the Kara-Bogaz Gol over the last two centuries by palynological analyses. Quaternary International 150, 52-70.

Leroy, S.A.G., Schwab, M.J., Costa, P.J.M., in press. Seismic influence on the last 1500-year infill history of Lake Sapanca (North Anatolian Fault, N-W Turkey). Tectonophysics.

Marret, F., Leroy, S.A.G., Chalié, F., Gasse F., 2004. New organic-walled dinoflagellate cysts from recent sediments of central Asian seas. Review of Palaeobotany and Palynology 129, 1-20.

Marret, F., Mudie, P., Aksu, A., Hiscott, R. N., 2009. A Holocene dinocyst record of a two-step transformation of the Neoeuxinian brackish water lake into the Black Sea. Quaternary International 197, 1-2, 72-86.

Marret, F., Zonneveld, K.A.F., 2003. Atlas of modern organic-walled dinoflagellate cyst distribution. Review of Palaeobotany and Palynology $125,1-200$.

McAndrews, J.H., Turton, C.L., 2007.Canada Geese dispersed cultigen pollen grains from prehistoric Iroquoian fields to Crawford Lake, Ontario, Canada. Palynology 31, 9-18.

Mertens, K.N., Verhoeven, K., Verleye, T., Louwye, S., Amorim, A., Ribeiro, S., Deaf A.S., Harding I. C., De Schepper S., González C., Kodrans-Nsiah M., De Vernal, A., Henry, M., Radi, T., Dybkjaer, K., Poulsen, N.E., FeistBurkhardt, S., Chitolie, J., Heilmann-Clausen, C., et al., 2009. Determining the absolute abundance of dinoflagellate cysts in recent marine sediments: The Lycopodium marker-grain method put to the test. Review of Palaeobotany and Palynology 157, 238-252. 
Morkoç, E., Tuğrul, S., Öztürk, M., Tufekçi, H., Egesel, L., Tüfekçi, V., Okay, O.S., Legović, T., 1998. Trophic characteristics of the Sapanca lake (Turkey). Croatica Chemica Acta 71, 303-322.

Mudie, P.J., Aksu, A.E., Yasar, D., 2001. Late Quaternary dinoflagellate cysts from the Black, Marmara and Aegean Seas: Variations in assemblages, morphology and paleosalinity. Marine Micropaleontology 43, 155-178.

Mudie, P.J., Rochon, A., Aksu, A.E., Gillespie, H., 2002. Dinoflagellate cysts, freshwater algae and fungal spores as salinity indicators in Late Quaternary cores from Marmara and Black seas. Marine Geology 190, 203-231.

Mudie, P.J., Rochon, A., Aksu, A.E., Gillespie, H., 2004. Late glacial, Holocene and modern dinoflagellate cyst assemblages in the Aegean-MarmaraBlack Sea corridor: statistical analysis and re-interpretation of the early Holocene Noah's Flood hypothesis. Review of Palaeobotany and Palynology $128,143-167$.

Mudie, P.J., Leroy, S.A.G., Marret, F., Gerasimenko, N., Kholeif, S.E.A., Sapelko, T., Filipova-Marinova, M., in press. Non-Pollen Palynomorphs (NPP): Indicators of Salinity and Environmental Change in the Black SeaMediterranean Corridor. In: Buynevich, I., Yanko-Hombach, V., Smyntyna, O., Martin, R., (eds), Geology and Geoarchaeology of the Black Sea Region: Beyond the Flood Hypothesis. Don Siegel (ed.), Syracuse University, USA. GSA. accepted Jan. 2009.

Ongan, T., 1982. Güney Marmara Bölgesi İçsu Ürünlerini Geliştirme ve Su Kaynaklarının Envanteri Projesi. Sapanca. İ.Ü.F.F. Hidrobiyoloji Araş. Enst., 178 pp. 
Özuluğ, M., 2008. The fish fauna of the Durusu Lake Basin (İstanbul-Turkey). IUFS Journal of Biology 67, 1, 73-79.

Pfannenstiel, M., 1944. Die diluvialen Entwicklungstadien und die Urgeschichte von Dardanellen, Marmarameer und Bosporus. Geologische Rundschau 43, 342-434.

Polat, N., Uğurlu, S. Kandemir, S. 2008. Aşağı Kızılırmak havzası (Samsun-Türkiye) balık faunası. Journal of Fisheries Sciences.com. 2, 3, 489-498.

Rathje, E.M., Karatas, I., Wright, S., Bachhuber, J., 2004. Coastal failures during the 1999 Kocaeli earthquake in Turkey. Soil Dynamics and Earthquake Engineering 24, 699-712.

Ryan, W.B., 2007. Status of the Black Sea flood hypothesis. In: Yanko-Hombach, V., Gilbert, A.S., Panin, N., Dolukhanov, P.M., (eds), The Black Sea flood question, changes in coastline, climate and human settlement. Springer, The Netherlands, pp. $63-88$.

Ryan, W.B., Pitman, W.C., 1998. Noah's Flood: the new scientific discoveries about the event that changed history. Simon \& Schuster, New York.

Şahin, Ş.K., Yıldııım, M.Z., 2007. The Mollusk fauna of Lake Sapanca (Turkey: Marmara) and some physico-chemical parameters of their abundance. Turkish Journal of Zoology 31, 47-52.

Santamaría, L., Klaassen, M., 2002. Waterbird-mediated dispersal of aquatic organisms: an introduction. Acta Oecologica 23, 115-119.

Şaşı, H., Balık, S., 2003. The distribution of three exotic fishes in Anatolia. Turkish Journal of Zoology 27, 319-322.

Schwab, M., Werner, P., Dulski, P., McGee, E., Nowaczyk, N., Bertrand, S., Leroy, S.A.G., 2009. Palaeolimnology of Lake Sapanca and identification 
of historic earthquake signals, Northern Anatolian Fault Zone (Turkey). Quaternary Science Reviews 28, 991-1005.

Schütt, H., 1988. The Danubian character of he Mollusc fauna of the Sapanca Gölü (Marmara region, Turkey). Zoology in the Middle East 2, 79-85. Sorrel, P., Popescu, S.-M., Head, M.J., Suc, J.-P., Klotz, S., Oberhänsli, H., 2006. Hydrographic development of the Aral Sea during the last 2000 years based on a quantitative analysis of dinoflagellate cysts.

Palaeogeography, Palaeoclimatology, Palaeoecology 234, 304-327.

Tanik, A., Baykal, B.B., Gönenç, E., Meriç, S., Öktem, Y., 1998. Effect and control of pollution in catchment area of Lake Sapanca, Turkey. Environmental Management 22, 407-414.

Traverse, A., 1978. Palynological analysis of DSDP Leg 42B (1975) cores from the Black Sea. In: Ross, D.A., Neprochnov, Y.P. et al. (Eds), Initial reports of the Deep Sea Drilling Project, 42, 2. Washington, pp. 993-1015.

Uğurlu, S., Polat, N., 2006. Miliç Irmağı (Terme, Samsun) Balık Faunası E.U. Journal of Fisheries and Aquatic Sciences 23, 3-4, 441-444.

Vasiliev, I., Krijgsman, W., Langereis, C.G., Panaiotu, C.E., Mațenco, L., Bertotti, G., 2004. Towards an astrochronological framework for the eastern Paratethys Mio-Pliocene sedimentary sequences of the FocYani basin (Romania). Earth and Planetary Science Letters 227, 231- 247.

Wall, D., Dale, B., Harada, K., 1973. Descriptions of new fossil dinoflagellates from the Late Quaternary of the Black Sea. Micropaleontology 19, 1, 1831. 


\section{Table}

Table 1. Mean physical, chemical and biological characters from several stations in Lake Sapanca between May 2004 and September 2005. TSS = total suspended solids. $\mathrm{SRP}=$ soluble reactive phosphorus $\mathrm{TP}=$ total phosphorus. Algal density measured by Akçaalan et al. (2007) and Albay (unpublished data).

\begin{tabular}{llll}
\hline Parametres & unit & mean & $($ max. - min. $)$ \\
\hline Temperature & ${ }^{0} \mathrm{C}$ & 17.6 & $(7.2-28.1)$ \\
Conductivity & $\mu \mathrm{Scm}^{-1}$ & 212 & $160-266)$ \\
$\mathrm{pH}$ & & 7.9 & $(7.9-8.7)$ \\
$\mathrm{TSS}$ & $\mathrm{mgL}^{-1}$ & 3.72 & $(0.76-7.02)$ \\
$\mathrm{SRP}$ & $\mu \mathrm{gL}^{-1}$ & 4.84 & $(3.8-19.2)$ \\
$\mathrm{TP}$ & $\mu \mathrm{gL}^{-1}$ & 13.6 & $(4.2-44.6)$ \\
$\mathrm{NO}_{2}+\mathrm{NO}_{3}$ & $\mu \mathrm{gL}^{-1}$ & 32.4 & $(6.4-88.2)$ \\
$\mathrm{SiO}_{2}$ & $\mu \mathrm{gL}^{-1}$ & 2434 & $(1642-2814)$ \\
$\mathrm{Algal}_{\text {density }}$ & $\left(\mathrm{Ind} \mathrm{mL}^{-1}\right)$ & 562 & $(288-1124)$ \\
\hline
\end{tabular}




\section{Captions}

Fig. 1: Location of Lake Sapanca in NW Turkey. LS = Lake Sapanca, GI = Gulf of Izmit. The grey strip between the Black Sea and the Gulf of Izmit shows the location of Sakarya Strait. Made with the help of Online Map Creation (www.aquarius.geomar.de, accessed July 2009).

Fig. 2: Location of the coring stations in Lake Sapanca. Catchment modified from Tanik et al. (1998). Image from Landsat N-35-40-2000, https://zulu.ssc.nasa.gov.

Fig. 3: Photographs of brackish and marine microfossils from Lake Sapanca. Horizontal bar is $20 \mu \mathrm{m}$.

1. Impagidinium caspienense, core SA03K $7.1,7.75-8.0 \mathrm{~cm}$

2-3. Dinoflagellate theca, core SA03K7.1, $3.75-4.00 \mathrm{~cm}$

4. Dinoflagellate theca, core SA03K7.1, 3.50-3.75 cm

5-6. Impagidinium caspienense, core SA03K7.1, 10.00-10.25 cm

7. Radiosperma corbiferum, core SA03K7.1, 2.50-2.75 cm

8. Brigantedinium sp., core SA03K7.1, $3.75-4.00 \mathrm{~cm}$

9. Spiniferites cruciformis with cytoplasm, core SA03K7.1, 9.00-9.25 cm

10. Radiosperma corbiferum, core SA03K $7.1,4.50-4.75 \mathrm{~cm}$

11. Brigantedinium sp. with cytoplasm, core SA03K7.1, 3.75-4.00 cm

12. Brigantedinium sp., core SA03K7.1, 10.00-10.25 cm

13. Spiniferites cruciformis, core SA03R6, section 7 at $2 \mathrm{~cm}$

14. Radiosperma corbiferum, core SA03K $7.1,3.00-3.25 \mathrm{~cm}$ 
Fig. 4

a: For core SA03K7.1 and core SA03R6, from left to right: first dating; second lithological logs with mass-movement events highlighted in grey ( $T=$ turbidite, $R$ = reworked horizon) and main lithozones (I to III); third pollen zones ( $\mathrm{K}$ for Kayak core, and Rr for Reasoner core) with mass-movements in grey, see Schwab et al. (2009) and Leroy et al. (in press) for further details; fourth: microfossil percentage records from Lake Sapanca with a 10 times exaggeration curve.

b: Concentration diagrams. 